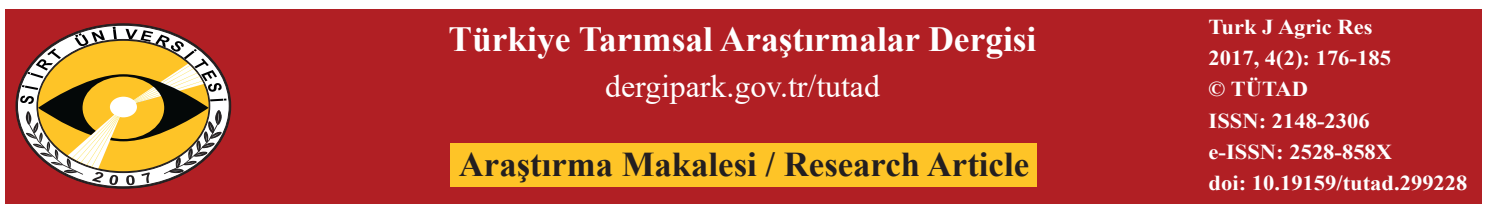

\title{
Verbascum cheiranthifolium Boiss. var. asperulum (Boiss.) Murb. ve Salvia limbata C. A. Mey. Ekstraktlarının Zea mays L. ve Portulaca oleraceae L. Tohumlarının Çimlenmesi Üzerine Allelopatik Etkisinin Araştırılması
}

\author{
Ömer BINGÖL ${ }^{1 *}$, Peyami BATTAL ${ }^{2}$ \\ ${ }^{1}$ Yüzüncü Yll Üniversitesi, Eğitim Fakültesi, Biyoloji Öğretmenliği Bölümü, Van, TÜRKIYYE \\ ${ }^{2}$ Yüzüncü Yll Üniversitesi, Fen Fakültesi, Biyoloji Bölümü, Van, TÜRKIYE
}

\begin{abstract}
Geliș Tarihi/Received: 21.03 .2017
Kabul Tarihi/Accepted: 28.06 .2017

*Sorumlu Yazar/Corresponding Author: omerbingol@yyu.edu.tr

Özet: Artan herbisit kullanımı ve bunların çevreye zararlarından dolayı alternatif bir mücadele yolu olan allelopati ile ilgili çalışmalara ihtiyaç duyulmaktadır. Bu amaçla, Verbascum cheiranthifolium var. asperulum ve Salvia limbata taksonlarının allelopatik potansiyellerinin belirlenmesi için su ve metanol ekstraktları kullanılmıștır. Verbascum cheiranthifolium var. asperulum ve Salvia limbata ekstraktların Portulaca oleraceae L. (semiz otu) ve Zea mays L. (misır) tohumlarının çimlenmeleri üzerine etkileri araștırılmıștır. Bu bitkilerinin su ve metanol ekstraktlarının mısır ve semizotu tohumlarına uygulamasında, artan ekstrakt konsantrasyonuna bağlı olarak radikula-plumula uzunlukları ile çimlenme yüzdelerinin azaldığı gözlenmiştir. Çalışma sonucunda daha ayrıntılı ve hassas çalışmalar yapılması durumunda, bu extraktların doğal herbisit olarak kullanılabileceği sonucuna varılmıştır.
\end{abstract}

An ahtar Kelimeler: Allelopati, çimlenme, plumula, radikula

\section{The Evaluation of Allelopathic Effects of Verbascum cheiranthifolium Boiss. var. asperulum (Boiss.) Murb. and Salvia limbata C. A. Mey. Extracts on Zea mays L. and Portulaca oleraceae L. Seed Germination}

\begin{abstract}
There is a need for studies on allelopathy, which is an anternative way of fighting, instead of herbicides and their harmful effects on environment. For this purpose, water and methanol extracts of Verbascum cheiranthifolium var. asperulum and Salvia limbata taxa were used to determine allelopathic potential. The effects of Verbascum cheiranthifolium var. asperulum and Salvia limbata extracts on seed germination of Portulaca oleraceae L. (purslane) and Zea mays L. (corn) were evaluated. Radicle-plumule lengths and germination percentages of corn and purslane were decreased with increased concentrations of water and methanol extracts onseeds. With more detailed and precise future studies, these extracts may be suggested as a natural herbicide.
\end{abstract}

Keywords: Allelopathy, germination, plumule, radicle

1. Giriş

Alternatif ve biyolojik mücadele olarak bilinen allelopati olayı aslında çok eski bir çalışma alanıdır. İlk kez M.Ö. eski Yunan devrinde Theoprastus, allelopati için "fitotoksite" terimini kullanmıştır; ancak, bilimsel olarak yapılan ilk tanımlama 1937 yılında Molisch tarafindan “Aynı habitatı paylaşan bitkilerin, biri tarafindan salınan maddelerin diğer bitki ve mikroorganizmaların gelişimini engelleyen doğa olayı" olarak (Molisch, 1937) tanımlamıştır. Yapılan sonraki çalışmalarda 
ise salınan madde etkisinin sadece engelleyici değil aynı zamanda teşvik edici özellikte de olabileceği fark edilmiş ve 1984 yılında Rice allelopati terimini "Bitkilerin, diğer bitki ve toprak canlıların gelişiminin teşvik edici ve/veya engelleyici etkisi” olarak geliștirmiștir (Rice, 1984). Allelopati terimi için yapılan son tanımlama ise sadece bitkileri değil aynı zamanda diğer canlı gruplarını da kapsamaktadır. $\mathrm{Bu}$ bağlamda Uluslararas1 Allelopati Topluluğu (International Allelopathy Society) 1996 y1lında allelopatiyi "Bitkiler, mikroorganizmalar, virüsler ve mantarlar tarafindan üretilen sekonder metabolitlerin, biyolojik sistem ve tarım alanlarındaki pozitif veya negatif etkileri" olarak tanımlamıştır (Torres ve ark., 1996).

Bugün bilinen birçok allelokimyasal bulunmaktadır. Bunlar arasında; suda çözünen organik asitler, düz zincirli alkoller, alifatik serisi, aldehitler, ketonlar, basit doymamış lakton, uzun zincirli yağ asitleri, çoklu aklin, naftakinon, antrakinon asit, kuinon bileşik, basit fenoller, benzoik asit ve türevleri, peptitler, alkaloidler, siyanohidrin, sülfit, glikosinolat, nükleotidler, fenolik asitler ve terpenoid bileşikler bilinen yaygın türlerdir (Song, 1990). Bitkilerde bulunan birçok sekonder metabolitin asıl fonksiyonları tam olarak bilinmemekle birlikte, bu metabolitlerin doğaya salınması bitki fizyologları ve ekologları için konuyu daha ilginç hale getirmektedir (Heldt, 1997). Allelokimyasalların tanımlanması hedef bitkideki etkinliğinin anlaşılabilmesi için, önemli bir parametre olarak görülmekle birlikte bu etkiyi bir tek kimyasala bağlamak doğru bir yorum olarak görülmez. Çünkü doğal şartlardaki allelokimyasal inhibisyon, birçok farklı bileşiğin sinerjik veya antagonist etkilerinden kaynaklanmış olabilir. Yapılan birçok laboratuvar deneyleri, aynı konsantrasyona sahip bir tek bileşiğin karışım solüsyonundan daha az toksik etki gösterdiğini ispatlamaktadır (Bulum ve ark., 1993). Bu yüzden tek bir bileşik ile yapılan allelopatik etki değerlendirmeleri aslında o bitkinin tam olarak allelokimyasal etkisini göstermez.

Allelokimyasallar; bitkinin kök, gövde, yaprak, polen, tohum ve çiçek gibi farklı kısımlarından sentezlenir ve kök sizıntıs1, toprak üstü kısımlardan süzülme, buharlaşma ve çürüme gibi farklı yollar ile çevrelerine salgılanırlar (Rice, 1984). Bitkilerdeki allelokimyasal konsantrasyonları ve toksisite değerleri, farklı doku ve organlar arasında bile değişkenlik gösterebilir (Ferguson ve Rathinasabapathi, 2012). Allelokimyasalların hücre bölünmesi, iyon ve su alınımı, fitohormon metabolizmas1, solunum, fotosentez, enzim fonksiyonlarını ve hatta gen ekspresyonunu etkilediğini gösteren çalışmalar bulunmaktadır (Inderjit ve Duke, 2003; Singh ve Thapar, 2003).

Allelopatik araştırmalar ile yapılan çalışma metotlarının genel tartışma konusu, ekolojik mekanizmalar üzerindeki etkisinin gösterilmesidir. Buradaki en önemli etki tarımsal araştırmalardaki yabanc1 ot kontrol mekanizmasıdır. Bu amaçla yüksek oranda allelopatik içeriği olan türlerin kullanılmas1, hedef bitkilerin uygulama bitkilerine olan hassasiyetleri, farklı ortam şartlarındaki allelopatik etkinin değerlendirilmesi ve alternatif bir yabanc1 ot metaboliti olarak kullanılması konuları öncelikli olarak göz önünde bulundurulmaktadır. Allelopatik araştırmaların tohum çimlenmesi uygulamalarında dikkat edilmesi gerekenler ise hedef bitki seçimi, osmotik potansiyel, 1şık ve sıcaklık şartları, $\mathrm{pH}$, uygulama konsantrasyonu, uygulanan tohum sayıs ve büyüklüğü, dormansi, uygulama periyodu ve tüm bu faktörlerin birbirleri ile olan etkileşimleridir (Kruse ve ark., 2000). Allelopatik türlerin yabanc1 ot kontrolünde kullanılması için allelokimyasalların çimlenme engelleyici özelliklerinin kullanılması, bitki kalıntılarının toprak yüzeyine uygulanması ve rotasyon çalışmalarında bir sonraki ürünün yabanc1 ot sayısını kontrol edilmesi gibi uygulamalar yapılmaktadır (Barnes ve Putnam, 1986; An ve ark., 1998). Bu çalışmalar yapılırken dikkat edilmesi gereken noktalar; en düşük seviyedeki fitotoksik etkiyi belirlemek, uygulama yapılacak maddenin topraktaki yarlanma ömrü ve parçalanması, diğer kültür bitkilerine, doğa ve insana olan etkileri ve bileşiğin etki mekanizmasının tam olarak anlaşılmasıdır. $\mathrm{Bu}$ kriterlere bağlı kalınarak yapılacak yabancı ot kontrolü ile birlikte moleküler ve biyoteknolojik çalışmalar ile desteklenmesi allelopatinin geleceğini, sentetik herbisitlerin yol açtığ 1 olumsuz sonuçlardan farklı kılacaktır.

Yapılan bu çalışmada, arazi gözlemlerine bakılarak allelopatik özelliğe sahip olduğu düşünülen 2 farklı familyaya ait 2 bitki türünün (Verbascum cheiranthifolium Boiss. var. asperulum (Boiss.) Murb.ve Salvia limbata C. A. Mey. allelopatik potansiyelleri araştırılmıştır. Bitkilerin seçiminde aromatik kokularının keskin olması, bulunduğu habitatlarda geniş yayılış göstermeleri ve etraflarında fazla bitki yetișmemesi dikkate alınmıștır. Çalıșmanın amacı; Verbascum cheiranthifolium Boiss. var. asperulum (Boiss.) Murb. ve Salvia limbata C. A. Mey. ekstraktlarının misir ve semizotu tohumlarının çimlenmesi üzerine etkilerini belirleyerek, alternatif bir mücadele modeli ortaya koymaktır. 


\section{Materyal ve Yöntem}

Bitkilerin allelopatik potansiyellerinin belirlenmesi amacı ile bitkilerin metanol ve su ekstraktlarının dört farklı konsantrasyonu kullanılmıştır. Kullanılan bu ekstraktların yabancı ot Portulaca oleraceae L. (semizotu) ve kültür bitkisi Zea mays L. (mısır) tohumlarının çimlenmeleri üzerine olan etkileri araştırılmıştır.

\subsection{Bitki seçimi}

Allelopati çalışmalarında dikkat edilmesi gereken en önemli kriter kullanılacak olan bitkilerin seçimidir. Seçilen bitkilerin allelopatik özelliğe sahip olması gerekir. $\mathrm{Bu}$ sebeple çalışmada kullanılacak olan bitkilerin seçiminde dikkat edilmesi gereken nokta çalş̧lacak olan bitkilerin farklı özelliklere sahip olmalarıdır. Doğu Anadolu Bölgesi'nin endemizm yönünden zengin bir bölge olduğu bilinmekle birlikte, bu bitkilerin allelopatik özellikleri çok fazla çalışılmamıştır. $\mathrm{Bu}$ nedenle bölgede, biri endemik ve diğeri de bulunduğu habitatta geniş yayılış gösteren toplam iki farklı bitki türü seçilmiştir. $\mathrm{Bu}$ bitkilerin seçiminde; aromatik kokularının keskin olması, bulunduğu habitatlarda geniş yayılış göstermeleri ve etraflarında fazla bitki yetişmemesi gibi faktörler dikkate alınmıstır. Endemik olan Verbascum cheiranthifolium var. asperulum bitkisi Van-Başkale 1833 m'de, Salvia limbata ise Van-Başkale 1850 m'de toplanmıştır. Bitkilerin teşhisinde Verbascum Huber-Morath (1978), Salvia Hedge (1982)'ye göre yapılmıştır.

\section{2. Çalışmada kullanılan hedef bitki tohumları}

Çalışmada hedef bitki materyali olarak; OSSK 602-Hibrit misır (Zea mays L.) çeşidi ve misır bitkisinde verim azalmasına neden olduğu bilinen semizotu (Portulaca oleracea L.) yabanc1 bitki tohumları ile çalışılmıştır. Misır tohumları Yüzüncü Y1l Üniversitesi Ziraat Fakültesi Bahçe Bitkileri Bölümü'nden, semizotu tohumları ise ticari olarak temin edilmiştir.

\subsection{Araziden toplanan Verbascum ve Salvia bitkilerin laboratuvar ortamına alınması}

Arazi çalışmalarında farklı lokalitelerden bez torbalar içerisinde getirilen Verbascum ve Salvia bitkileri, toz ve kontaminasyonları uzaklaştırmak için önce musluk suyu ile daha sonra saf su ile yıkanmıștır. Araziden getirilen Verbascum ve Salvia bitkilerine karışmı̧̧ olan, farklı bitki türleri tek tek ayıklanmıştır. Laboratuvar ortamında kurutma kâğıtları üzerine serilen Verbascum ve Salvia bitkileri havada kurumaya bırakılmıştır. Bitkilerin alt kısımlarındaki kurutma kâğıtları gün aşırı değiştirilerek, nem ve küflenmeyi önlemek amaciyla da bitkiler her gün alt üst edilmiştir. Laboratuvar ortamında 10 gün boyunca kurutulan bitkilerin toprak üstü (gövde+yaprak) kısımları ve kökler ayrılarak, toprak üstü kısımları labaratuvar blenderında toz haline getirilmiştir (Türker ve ark., 2008).

\section{4. Çimlenme denemesinin kurulması}

Bitki ekstraktlarının tohum çimlenmesi üzerine etkileri araştırılmadan önce hem kültür bitkisi hem de yabanc1 ot tohumlarına etki edecek konsantrasyonlar bulunmaya çalışılmıştır. Misır ve semizotu için letal konsantrasyonlar bulunmuş ve bu etkinin her bitki ekstraktı için farkl konsantrasyonlarda olduğu tespit edilmiştir. Türlerin birbirleri ile aynı oranlarda mukayese edilebilmesi için tüm bitki ekstrakları için ortak konsantrasyonların kullanılmasına karar verilmiştir. Böylece bitki ekstraklarının aynı konsantrasyonlardaki etkileri karşılaştırılmıştır. Ayrıca çimlenme denemesi öncesinde tohumlara tetrazolium canlilık testi yapılarak tohumların canlılık yüzdeleri tespit edilmiştir.

Çimlenme denemesi uygulanması için bitkilerin metanol ve su (saf su) ekstraktları hazırlanmıştır. Literatür çalışmaları incelendiğinde allelopatik çalışmalarda, çözgen olarak genellikle metanol ve su çözgenlerinin kullanıldığ görülmüştür. Kullanılan solvent türü ekstrakta bulunan allelokimyasal içeriğini belirgin şekilde etkilemektedir. Azotlu bileşiklerin suda çözünmesinden dolayı su ekstraktı, terpenler ve fenolik bileşiklerin büyük bir kısmının suda çözünmemesinden dolayı da metanol ekstraktı kullanılmıştır. Çalışmaya geçilmeden önce her bitki için en uygun konsantrasyonun belirlenmesi amacı ile ön denemeler yapılmıştır. Ön deneme çalışmalarında, \% $0.5, \% 1, \%$ 2, \% 3, \% 4, \% 5, $\% \quad 6, \%$ 7, \% $8, \%$ 9, \% $10, \% 11$ ve $\% 12^{\prime}$ lik konsantrasyonlar her iki hedef tohuma uygulanmıştır. Ön denemeler sonucunda, başlangıç konsantrasyonu \% 9 olmak üzere \% 3, \% 5, \% 7 , $\%$ 9'luk konsantrasyonlarin kullanılmasina karar verilmiştir. $\mathrm{Bu}$ amaçla bitkilerin saf su ve metanol ekstraktları 24 saat boyunca 200 rpm'de çalkalayıcıda bekletilmiştir. Ekstraktlar 4 kat tülbent bezinden geçirildikten sonra 4000 rpm'de santrifüj edilmiştir. Tüm bitkiler için \% 9'luk stok solüsyon hazırlanmış ve ekstraktlar kendi çözgenleri ile stok solüsyondan seyreltilmiştir (Ashrafi ve ark., 2008). Saf su ile hazırlanan su ekstraktları direkt olarak kullanılmış, metanol ekstraktları ise evaporatörde uçurulduktan sonra su fazına alarak kullanılmıştır. $\mathrm{Bu}$ şekilde ekstraktlar hazırlandıktan sonra çimlenme uygulamasına geçilmiștir (Jefferson ve Pennacchio, 2003). 
Çimlenme denemesi için $9 \mathrm{~cm}$ çaplı petri kapları kullanılmıştır. Çalışmada kullanılan petri kapları ve kurutma kağıtları otoklavda $121{ }^{\circ} \mathrm{C}$ 'de 30 dakika bekletilerek steril edilmiştir. Tohumların sterilizasyonu için ise Portulaca oleracea \% 1'lik, Zea mays tohumları ise \% 2'lik hipoklorit içerisinde 5 dakika bekletilmiştir. Tohumlar petri kaplarına yerleştirilmeden önce boyutlarına bağlı olarak her petri kabına mısır için 8 , semizotu için ise 200 tohum yerleştirilmiştir. Belli sayıda tohum kullanıldığından çimlenme yüzdeleri sağlıklı şekilde hesaplanmıştır. Petri kaplarının alt kısımlarına steril çift kat kurutma kağıdı yerleştirilerek tohumlar içerisine bırakılmıştır. Tohumların üzerlerine hazırlanan ekstraktlardan belirlenen konsantrasyonlarda saf su ve metanol ekstraktları ilave edilmiştir. Kontrol grupları için aynı miktarda saf su kullanılmıştır. Ekstraktlar otomatik pipetler yardımı ile petri kaplarına ilave edilmiş ve petri kaplarının etrafları kontaminasyon ve nem kaybını önlemek için parafilm ile kaplanmıştır (Oyun, 2006). Her bitki için kontrol grubu ile birlikte toplam 5 grup oluşturulmuş, böylece tohum çimlenmesi inhibisyonu için en uygun konsantrasyonlar belirlenmiştir. $\mathrm{Su}$ ve metanol ekstraktlarının çimlenme uygulaması iklim dolabında $27 \pm 2{ }^{\circ} \mathrm{C}$ 'de on saat aydınlik (5000 lux) ve 14 saat karanlik fotoperiyot ile 7 gün boyunca bekletilmiştir. İklim dolabının sıcaklık ve fotoperiyot şartları tüm hedef tohumların optimum çimlenme istekleri araştırıldıktan sonra ortalama değerler olarak hesap edilmiştir.

Her uygulama 5 tekerrürlü olacak şekilde denemeler kurulmuştur. Çimlenme denemeleri sonucunda her gurubun çimlenme yüzdeleri ve radikula, plumula uzunlukları ölçülmüştür (Mao ve ark., 2006).

Çimlenme denemesi sonucunda tohumların çimlenme yüzdesi sayma yöntemi, radikula ve plumula uzunlukları ise ölçme yöntemi ile belirlenmiştir.

Verbascum ve Salvia bitkilerinin su ve metanol solventleri ile hazırlanan ekstraktlardan \% 3, \% 5, $\%$ 7, \% 9'luk konsantrasyonlar misir ve semizotu tohumlarına uygulanmıştır. Steril petri kaplarında gerçekleştirilen uygulamalarda mis ir ve semizotu tohumlarının ve fidelerinin çimlenme yüzdeleri ve radikula-plumula uzunlukları tespit edildimiştir. Çimlenme yüzdesinin hesaplanması aşağıda verilen formül kullanılarak bitki ekstraktlarının çimlenme yüzdesi üzerine etkileri hesaplanmıştır.

$$
1-\left[\frac{\text { Uygulama }}{\text { Kontrol }}\right] x 100
$$

\section{Bulgular ve Tartışma}

\subsection{Verbascum cheiranthifolium var. asperulum su ve metanol ekstraktlarının çimlenme üzerine etkisi}

Verbascum cheiranthifolium var. asperulum taksonunun su ekstraktının çimlenmeye etkisi incelendiğinde; artan ekstrakt konsantrasyonuna bağlı olarak çimlenme yüzdesinin azaldığı ve en düşük çimlenme yüzdesinin $\% \quad 9$ ekstrakt konsantrasyonu ile semizotu tohumlarında gerçekleştiği (\% 59) görülmüştür. Ancak ayını konsantrasyonun misır tohumlarına aynı etkiyi göstermediği tespit edilmiştir. En yüksek konsantrayon olan $\% \quad 9 \quad$ ekstrakt konsantrasyonunda, misir tohumlarinın çimlenmesinin (\% 87.5), semizotuna göre daha az etkilediği tespit edilmiştir (Şekil 1).

Verbascum cheiranthifolium var. asperulum taksonunun metanol ekstraktı, su ekstraktında olduğu gibi mısır bitkisinin çimlenme yüzdesinde önemli bir azalmaya yol açmamıştır. En yüksek ekstrakt konsantrasyonu olan \% 9'da misir tohumlarının $\quad \% \quad 82.5$ oranında çimlendiği görülmüştür. Metanol ekstraktının asıl etkisinin semizotu tohumları üzerine olduğu görülmüştür. $\% \quad 3$ ve $\% \quad$ 5'lik ekstrakt konsantrasyonları uygulamasından itibaren önemli bir düşüş belirlenmiştir. \% 7 ekstrakt konsantrasyonunda tohum çimlenmesi \% 68.2 değerine düşerken, $\%$ 9'luk ekstrakt konsantrasyonunda ise ani bir düşüşle çimlenme yüzdesinin ancak \% 1.1 olduğu görülmüştür (Şekil 2).

Yapılan ölçüm sonuçlarında $V$. cheiranthifolium var. asperulum taksonunun su ve metonol ekstraktlarının artan konsantrasyona bağlı olarak mısır ve semizotu bitkilerinde radikula ve plumula uzunluklarında azalmaya yol açtı̆̆ gözlenmiştir. Ayrıca artan ekstrakt konsantrasyonuna bağlı olarak radikulada tüylenme ve kıvrılmaların arttığ1 tespit edilmiştir. Verbascum cheiranthifolium var. asperulum su ekstrakt uygulamasinın misır ve semizotunda ilk uygulama olan \%3'ten itibaren radikula ve plumula uzunluğunda önemli bir azalmaya yol açtığ1 görülmüştür. Metonol ekstraktı uygulamasında radikula ve plumula uzunluklarının su uygulamasına göre daha fazla azaldığ \% 9 ekstrakt konsantrasyonlarının semizotunda plumula gelişimini tamamen engellediğ belirlenmiştir (Tablo 1).

Kontrol gruplarıyla karşılaştırıldığında \% 3'lük bitki ekstraksiyonlarından başlayarak tüm ekstrakt konsantrasyonların misir ve semizotu bitkilerinde azalttığ 1 , mısır bitkisine oranla semizotu bitkisinin 
daha fazla etkilendiği tespit edilmiştir. Misır ve semizotu bitkilerinde en yüksek radikula ve plumula uzunlukları kontrolde, en düşükradikula ve plumula uzunlukları ise \% 9'luk metanol ekstraktı uygulamalarında olduğu gözlenmiştir (Tablo 1).

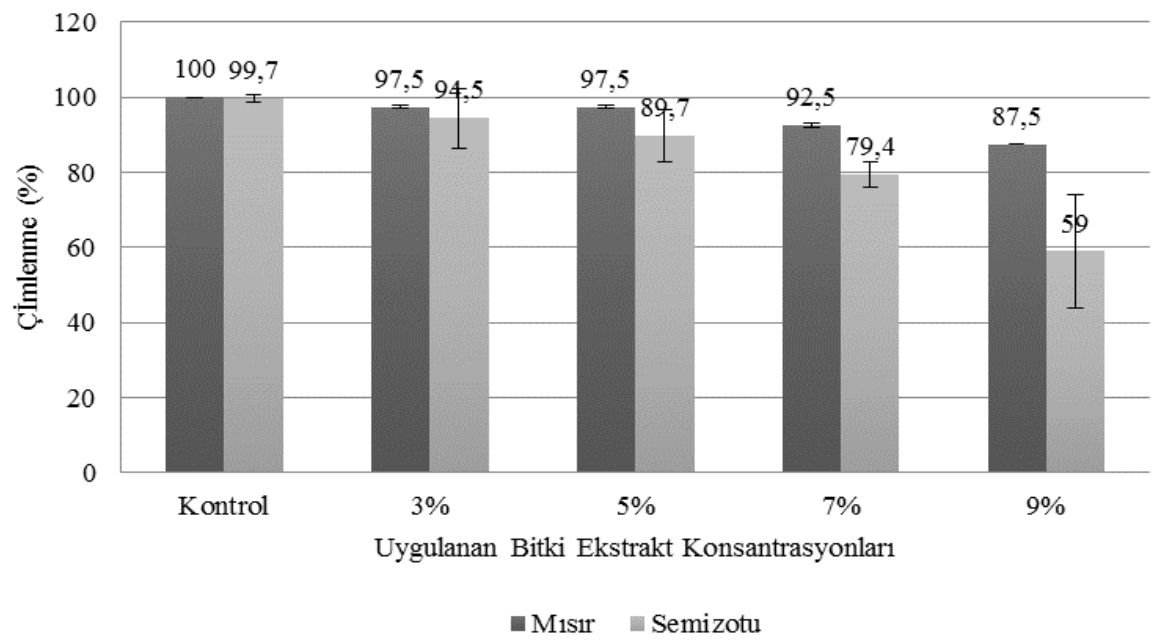

Şekil 1. Verbascum cheiranthifolium var. asperulum su eks traktı uygulanan mıs ir ve semizotu tohumlarının çimlenme yüzdeleri

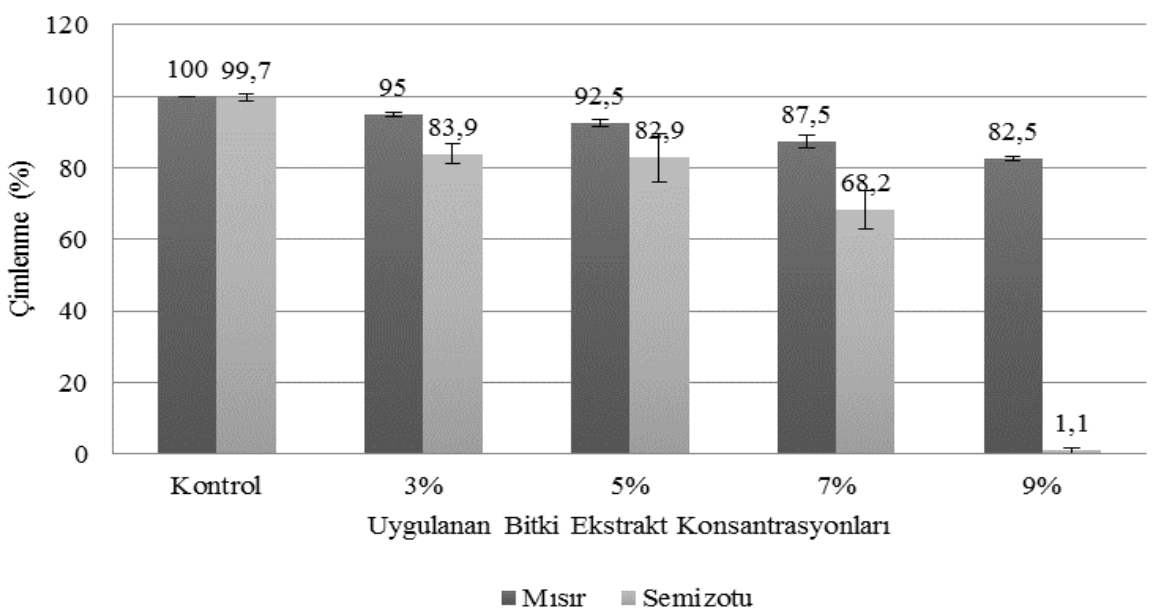

Şekil 2. Verbascum cheiranthifolium var. asperulum metanol ekstraktı uygulanan misır ve semizotu tohumların çimlenme yüzdeleri

Tablo 1. Verbascum cheiranthifolium var. asperulum su ve metanol ekstraktlarının uygulandığ mısır ve semizotu tohumlarında radikula ve plumula uzunlukları $(\mathrm{cm})$

\begin{tabular}{lccccc}
\hline Uygulamalar & Kontrol & $\% 3$ & $\% 5$ & $\% 7$ & $\% 9$ \\
\hline Radikula (Su ekstrakt1) & $9.49 \pm 1.05$ & $2.69 \pm 0.32$ & $2.39 \pm 0.42$ & $1.82 \pm 0.61$ & $0.56 \pm 0.02$ \\
Plumula (Su ekstrakt1) & $2.56 \pm 0.37$ & $2.05 \pm 0.25$ & $1.48 \pm 0.21$ & $1.23 \pm 0.27$ & $0.50 \pm 0.02$ \\
Radikula (Metanol ekstrakt1) & $9.49 \pm 1.05$ & $0.49 \pm 0.01$ & $0.46 \pm 0.01$ & $0.40 \pm 0.02$ & $0.24 \pm 0.06$ \\
Plumula (Metanol ekstrakt1) & $2.56 \pm 0.37$ & $0.93 \pm 0.03$ & $0.86 \pm 0.37$ & $0.82 \pm 0.03$ & $0.30 \pm 0.03$ \\
\hline \multicolumn{7}{c}{ Portulaca oleracea } \\
\hline Radikula (Su ekstrakt1) & $2.70 \pm 0.08$ & $1.02 \pm 0.08$ & $0.60 \pm 0.12$ & $0.30 \pm 0.01$ & $0.17 \pm 0.07$ \\
Plumula (Su ekstrakt1) & $1.51 \pm 0.12$ & $1.04 \pm 0.17$ & $0.82 \pm 0.05$ & $0.55 \pm 0.12$ & $0.30 \pm 0.08$ \\
Radikula (Metanol ekstrakt1) & $2.70 \pm 0.08$ & $0.46 \pm 0.06$ & $0.28 \pm 0.03$ & $0.22 \pm 0.03$ & $0.09 \pm 0.01$ \\
Plumula (Metanol ekstrakt1) & $1.51 \pm 0.12$ & $0.47 \pm 0.07$ & $0.30 \pm 0.07$ & $0.00 \pm 0.00$ & $0.00 \pm 0.00$ \\
\hline
\end{tabular}




\subsection{Salvia limbata su ve metanol ekstraktlarının çimlenme üzerine etkisi}

Salvia limbata su ve metanol ekstrakt1 uygulanan misır ve semizotu tohumlarında artan ekstrakt konsantrasyonuna bağ lı olarak radikulaplumula uzunlukları ile çimlenme yüzdelerinin azaldığ1 gözlenmiştir.

Salvia limbata su ekstraktı uygulamasının, mısır ve semizotu tohumlarının çimlenmesini, ekstrakt konsantrasyonu artışına bağlı olarak azalttığ1 tespit edilmiştir. Misır tohumlarının çimlenme yüzdelerinde $\% 7$ ekstrakt uygulamasına kadar belirgin bir fark gözlenmezken, semizotu tohumlarının çimlenme yüzdelerinde \% 3 ekstrakt uygulamasindan itibaren önemli azalmalar kaydedilmiştir. Semizotu tohumlarında \% 7 ekstrakt konsantrasyonu uygulamasinda çimlenme oranı \% 44.8 olarak hesaplanmıștır. Misır ve semizotunda en düşük çimlenme oranı $\% 9$ ekstrakt konsantrasyonu uygulamasinda sirasiyla $\% 81.5$ ve \% 6.2 olarak tespit edilmiştir (Şekil 3).
Salvia limbata metanol ekstraktı uygulaması su uygulamasında olduğu gibi misır tohumlarından çok semizotu tohumlarına etki etmiștir. Misır tohumlarında ilk üç ekstrakt uygulamasında belirgin bir azalma gözlenmezken \% 9 ekstrakt konsantrasyonunda çimlenme yüzdesinin \% 50 oranında azaldığı gözlenmiştir. Semizotu tohumlarında çimlenme yüzdesinin önemli oranda etkilendiği, $\% \quad 3$ ekstrakt konsantrasyonunda çimlenme \% 80.7, \% 5 ekstrakt konsantrasyonunda \% 23.8'e kadar azaldığ1, \% 7 ve \% 9 ekstrakt konsantrasyonlarında ise çimlenmenin olmadığ tespit edilmiştir (Şekil 4).

Salvia limbata su ve metanol ekstraktları ile yapilan uygulamalarda artan ekstrakt konsantrasyonuna bağlı olarak hedef bitkilerde radikula ve plumula uzunluklarının azaldığ gözlenmiştir. Metanol ekstraktı uygulamasının su uygulamasına göre daha fazla etki ettiği ve semizotu tohumlarının radikula-plumula uzunluklarının misır bitkisine göre daha fazla azaldı̆̆ 1 belirlenmiştir (Tablo 2).

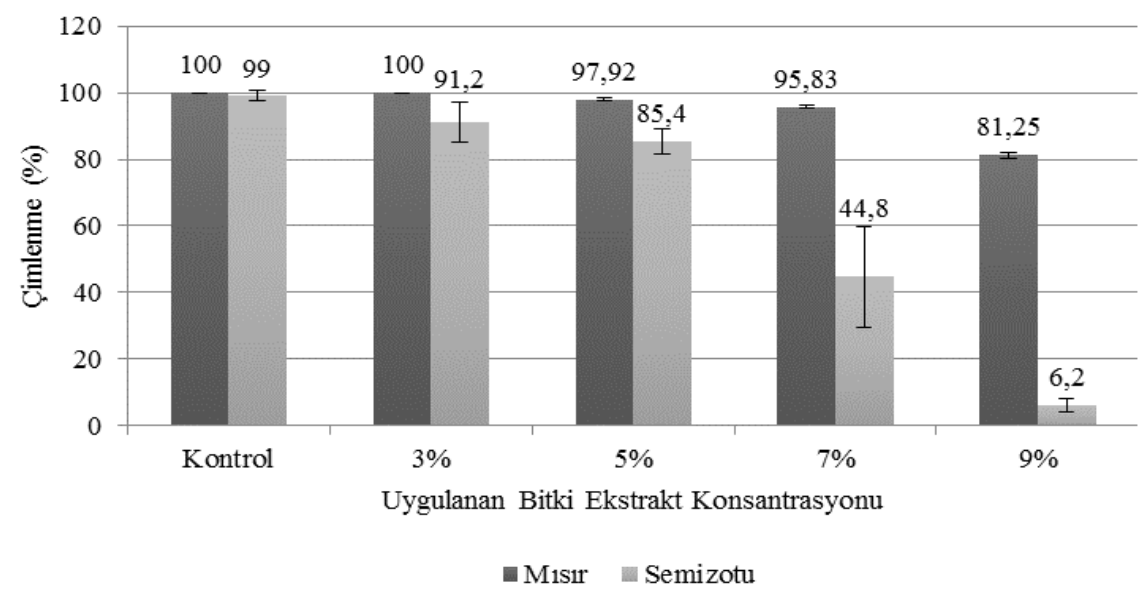

Şekil 3. Salvia limbata su eks traktıuygulanan mıs ır ve semizotu tohumlarının çimlenme yüzdeleri

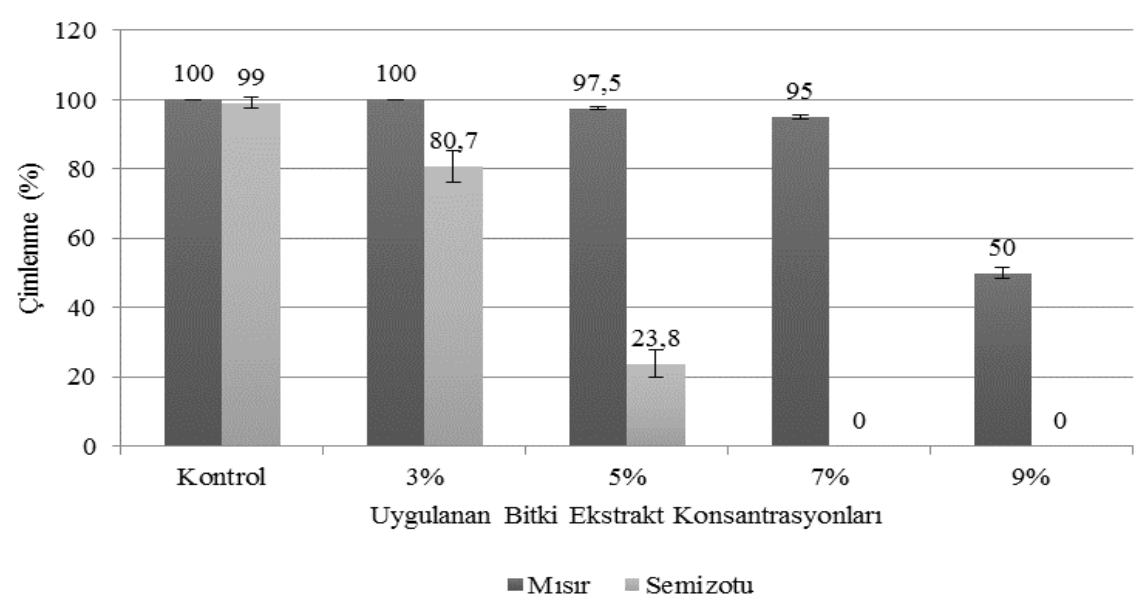

Şekil 4. Salvia limbata metanol eks traktı uygulanan mıs ır ve semizotu tohumlarının çimlenme yüzdeleri 
Tablo 2. Salvia limbata su ve metanol ekstraktlarının uygulandığı mıs ır ve semizotu tohumlarında radikula ve plumula uzunlukları (cm)

\begin{tabular}{|c|c|c|c|c|c|}
\hline & Kontrol & $\% 3$ & $\% 5$ & $\% 7$ & $\% 9$ \\
\hline \multicolumn{6}{|c|}{ Zea mays } \\
\hline Radikula (Su ekstraktı) & $10.4 \pm 1.02$ & $7.24 \pm 0.92$ & $3.04 \pm 0.95$ & $3.02 \pm 0.35$ & $2.79 \pm 0.68$ \\
\hline Plumula (Su ekstraktı) & $2.86 \pm 0.49$ & $2.10 \pm 0.45$ & $1.90 \pm 0.41$ & $1.53 \pm 0.10$ & $1.52 \pm 0.08$ \\
\hline Radikula (M etanol ekstraktı) & $10.4 \pm 1.02$ & $4.71 \pm 0.73$ & $2.70 \pm 0.46$ & $1.80 \pm 0.21$ & $1.78 \pm 0.27$ \\
\hline Plumula (M etanol ekstraktı) & $2.86 \pm 0.49$ & $1.81 \pm 0.26$ & $1.74 \pm 0.20$ & $1.60 \pm 0.37$ & $1.58 \pm 0.49$ \\
\hline \multicolumn{6}{|c|}{ Portulaca oleracea } \\
\hline Radikula (Su ekstraktı) & $2.76 \pm 0.36$ & $1.09 \pm 0.05$ & $0.33 \pm 0.01$ & $0.12 \pm 0.03$ & $0.00 \pm 0.00$ \\
\hline Plumula (Su ekstraktı) & $1.46 \pm 0.03$ & $1.28 \pm 0.11$ & $0.58 \pm 0.08$ & $0.08 \pm 0.00$ & $0.00 \pm 0.00$ \\
\hline Radikula (M etanol ekstraktı) & $2.76 \pm 0.36$ & $0.29 \pm 0.08$ & $0.14 \pm 0.03$ & $0.00 \pm 0.00$ & $0.00 \pm 0.00$ \\
\hline Plumula (M etanol ekstraktı) & $1.46 \pm 0.03$ & $0.44 \pm 0.02$ & $0.00 \pm 0.00$ & $0.00 \pm 0.00$ & $0.00 \pm 0.00$ \\
\hline
\end{tabular}

İki bitkiye ait su ekstraktları değerlendirildiğinde misır bitkisinde $\% \quad 7$ ve semizotu bitkisinde ise \% 3 konsantrasyondan itibaren belirgin bir çimlenme inhibisyonun olduğu tespit edilmiştir. Bitki ekstraktlarının tüm konsantrasyon uygulamalarının semizotu tohumlarının çimlenme yüzdesinde düşüşe yol açtığ1 saptanmıştır. Çimlenmedeki inhibisyon, Verbascum ekstrakt uygulamasinda \% 41 ve Salvia ekstrakt uygulamasinda \% 93.8 olarak tespit edilmiştir. Ayrıca Salvia bitkisinin \% 7'lik konsantrasyonunun semizotu tohumlarına uygulanmasinda \% 55.2'lik bir çimlenme inhibisyonu belirlenmiştir. Verbascum ve Salvia su ekstraktlarının misır tohumlarının çimlenme yüzdesinde önemli bir azalmaya yol açmadı̆̆ belirlenmiştir. $\mathrm{Bu}$ farklığın bitki içeriğinde bulunan allelokimyasal çeşitliliğinden, çözücünün allelokimyasalların daha hızlı bozulmasina neden olmasından ve tohumların farklı büyüklüklere sahip olmasından kaynaklandığ 1 düşünülmektedir. Küçük tohumların büyük tohumlara oranla toksik etkiden daha fazla etkilendiği bilinen bir gerçektir (Dayan ve Duke, 2006). Çimlenme inhibisyonu çalışmalarında çözücü olarak genelde su kullanılmaktadır. Bununla birlikte bitkide bulunan fitokimyasal maddeler stabil olmadiklarından su ortamında kısa sürede bozulabilirler (Shan ve ark., 2005).

Bitkilerin metanol ekstraktları değerlendirildiğinde misır tohumlarına, Verbascum bitkisinin $\% \quad 3$ ve Salvia bitkisinin \% 7 konsantrasyondan itibaren etki ettiği belirlenmiştir. Semizotu tohumlarına etkileri incelendiğinde ise; iki bitkinin $\% \quad 3$ konsantrasyondan itibaren semizotu tohumlarının çimlenme yüzdesinde önemli azalmalara yol açtı̆̆ 1 saptanmıştır. Semizotu tohumlarına uygulanan \%9'luk konsantrasyonda, Verbascum bitkisi \% 98.9 ve Salvia bitkisi \% 100 çimlenme inhibisyonuna neden olduğu tespit edilmiștir. Bunlara ilave olarak Salvia bitkisinin \% 5'lik konsantrasyonda bile \% 77.2'lik bir inhibisyon gösterdiği ve \% 7'lik konsantrasyonda da hiçbir tohumun çimlenmediği görülmüştür.

Allelopatik çalışmalarda inhibisyonun derecesi büyük oranda konsantras yona ve kullanılan solvent türüne bağlı olarak değişir (Jeffersona ve Pennacchio, 2003). Genel olarak inhibisyonun derecesi konsantrasyon artışına paralel olarak artmaktadır (Daizy ve ark., 2002; Han ve ark., 2008; Jinhu ve ark., 2012; Wang ve ark., 2017). Çalş̧mamızda da benzer sonuçlar elde edildi. Konsantrasyon artışına bağlı olarak çimlenme yüzdesinin azaldığ 1 ve metanol ekstraktının su ekstraktından daha etkili olduğu tespit edilmiştir. Rhus typhina'nın su solventi ile kırmızı ve yeşil yapraklarından hazırlanan ekstraktların, artan ekstrakt konsantrasyonuna bağlı olarak tohum çimlenmesi ve büyümesini önemli ölçüde inhibe etmektedir (Wang ve ark., 2017). Çalışmamızda da su ekstraktı denemelerinde artan ekstrakt konsantrasyonuna bağlı olarak tohum çimlenmesinin azaldı̆̆ tespit edilmiştir. Kullanılan solvent türü ekstrakta bulunan allelokimyasal içeriğini belirgin şekilde etkilemektedir. Bitkisel kökenli sekonder metabolitler, terpenler, fenolik ve azotlu bileşikler olmak üzere üç ana guruba ayrilırlar. Terpenler ve fenolik bileşiklerin büyük bir kısmı suda çözünmezler (Taiz ve Zeiger, 2008). Çalışmamızda kullanılan metanol ekstraktının sekonder metabolitlerden terpenler ve fenolik bileşikleri ortaya çıkardığı düşünülmektedir. Metanol ekstraktlarında meydana gelen bu inhibisyonun genel itibariyle terpenler ve fenolik bileşiklerden kaynaklandığ 1 beklenmektedir.

Tohum çimlenmesi ile yapılan allelopatik çalışmalarda, radikula ve plumula uzunluklarına olan etkilerin belirlenmesi en çok kullanılan parametrelerdir (Chon ve ark., 2002; Oueslati, 2003; Dandelot ve ark., 2008). Radikula inhibisyonun, daha hassas ve daha fazla etkilendiği rapor edilmiştir (Abdelgaleil ve Hashinaga, 2007; Amoo ve ark., 2008). Benzer çalışmalarda hedef bitkilerin toksik bitki ile etkileşim süresinin uzamasının, etki derecesini arttırdığını rapor 
etmiştir (Jinhu ve ark., 2012). Bizim çalışmamızda da tohumlar yedi gün gibi uzun bir süre bitki ekstraktları ile muamele edilmiş olduğundan, benzer şekilde radikula uzunluğunun plumula uzunluğuna oranla daha fazla etkilendiği tespit edilmiştir. $\mathrm{Bu}$ durum toksik etkiye maruz kalan tohumların ciddi zararlara neden olması veya allelokimyasalların özellikle hücre bölünmesi, hormon sentezi ve enzim aktivitesi gibi reaksiyonları etkilemesinin bir sonucu olabilir (Oyun, 2006).

Yan yana bulunan iki bitki arasında kök gelişimlerine olacak herhangi bir etki iki türün arasındaki rekabet açısından önemlidir (Noguchi ve ark., 2009). Hedef bitkinin kök gelişiminin inhibe edilmesi allelokimyasalı salan bitki için mineral, besin ve su alınımı ve yayılma açısından avantaj sağlamaktadır. $\mathrm{Bu}$ bağlamda yapılan çalışmalarda kök gelişimine etki edebilecek allelokimyasalların doğal herbisit olarak kullanılabileceği düşünülmektedir (Maharjan ve ark., 2007; Zhang ve Fu, 2009).

Bitki ekstraktlarının radikula ve plumula uzunlukları üzerine etkileri incelendiğinde genel olarak semizotu tohumlarının misır tohumlarına oranla çok daha fazla etkilendiği ve Salvia bitkisinin su ve metanol ekstraktlarının \% 9'luk konsantrasyonunda semizotu tohumlarında radikula ve plumula çıkışının olmadığ belirlenmiştir. $\mathrm{Bu}$ etki farkı, tohumların dayanıklılı̆̆1, adaptasyonu, testa kalınlığ1 ve nişasta içeriğine göre farklılık göstermektedir (Daizy ve ark., 2002). İnhibisyon etkisi ilk ve son kullanilan konsantrasyona, hedef tohum çeşitliliğine göre farklılık göstermektedir (Jeffersona ve Pennacchio, 2003). Yabanc1 otlardan salınan allelokimyasallar kök ve sürgün gelişimini bozar ve aynı zamanda fide çıkışında çeşitli zararlara neden olabilir (Dimitrović ve ark., 2015). Bizim çalışmamızda da benzer sonuçlar elde edilmiştir. Radikula ve pulumula gelişiminin önemli ölçüde azaldığı tespit edilmiştir.

Metanol solventi ile hazırlanan orman pirinci ekstraktları, dikloromethan ve hexan ile hazırlanan orman pirinci solvent ekstraktlarından daha etkilidir (Sitthinoi ve ark., 2017). Bizim çalışmamızda ise metanol ekstraktlarının su ekstraktlarından daha fazla etkili olduğu tespit edilmiştir. Misır tohumları üzerine su ve metanol ekstraktlarının etkileri incelendiğinde en büyük inhibisyon etkisinin Verbascum'un metanol ekstraktında en düşük etkinin ise Salvia'nın su ekstraktında olduğu tespit edilmiştir. Semizotu tohumları için ise en yüksek inhibisyon etkisinin Salvia'nın metanol ekstraktında olduğu belirlenmiştir. Salvia bitkisinde olduğu gibi aynı bitkinin iki farklı solventi kullanıldığında bu kadar farklı etki göstermesi, solvent türünün etki derecesi açısından oldukça önemli olduğunun göstergesidir. Ayrica allelopatik etkiye sahip olduğu bilinen özellikle fenolik asitlerin bazı bitki türlerinde türe spesifik olduğu ve bu spesifik bileşiklerin inhibisyonda etkili şekilde rol oynadıklanı düşünülmektedir (Wu ve ark., 1998). Farkl çalışmalarda monoterpenlerin de yüksek fitotoksik etki gösterdiği belirlenmiştir. Esansiyel yă grubunda bulunan monoterpenlerin plumula gelişiminde anatomik ve fizyolojik değişikliklere neden olduğu, DNA sentezini etkilediği ve sitoplazmada lipit birikimine neden olduğu rapor edilmiştir (Salmaci ve ark., 2007).

Çimlenme inhibisyonunda olduğu gibi radikula ve plumula uzunluklarındaki inhibisyonun da artan konsantrasyona bağlı olarak arttığ1 tespit edilmiştir. Bazı çalışmalarda allelokimyasal uygulamasının radikula ve plumula gelişimini teşvik edici etki gösterdiği açıklanmıştır (Tefera, 2002; Dandelot ve ark., 2008). Ancak bizim çalışmamızda böyle bir durum söz konusu değildir.

\section{Sonuçlar}

Yapılan çalıșmasında iki farklı bitkiye ait allelopatik potansiyeller çalışılmıştır. Verbascum ve Salvia bitkilerine ait su ve metanol ekstraktlarının semizotu tohumlarının çimlenmesini mısır tohumlarına oranla daha fazla inhibe ettiği ayrıca radikula ve plumula uzunlukları değerlendirildiğinde yine semizotu bitkisinin misır bitkisine oranla daha fazla etkilendiği tespit edilmiştir. Elde edilen sonuçlara bakıldı̆̆ında bu bitkilere ait ekstraktların doğal mücadele amaçlı kullanılabilmesi mümkündür. Ancak tüm bu sonuçlar neticesinde allelokimyasalların hedef bitkiye, hedef dokuya ve nihayet hedef hücreye nasıl etki ettiği halen sir olarak kalmaktadır. Çalışma bitkileri üzerinde daha ayrıntılı ve hassas çalışmalar yapılması durumunda, doğaya uygulanabilirlik açısından bu bitkilerden fayda görüleceği öngörülmektedir.

\section{Kaynaklar}

Abdelgaleil, S.A.M., Hashinaga, F., 2007. Allelopathic potential of two sesquiterpene lactones from Magnolia grandiflora L. Biochemical Systematics and Ecology, 35(11): 737-742.

Amoo, S.O., Ojo, A.U., Staden, J.V., 2008. Allelopathic potential of Tetrapleura tetraptera leaf extracts on early seedling growth of five agricultural crops. South African Journal of Botany, 74(1): 149-152.

An, M., Pratley, J., Haig, T., 1998. Allelopathy: From concept to reality. In Proceeding 9 th Australian Agronomy Conference, September 24-29, Wagga Wagga, Australia, p. 563-566. 
Ashrafi, Y.Z., Sadeghi, S., Mashhadi, R.H., Hassan, A.M., 2008. Allelopathic effects of sunflower (Helianthus annus) on germination and growth of wild barley (Hordeum spontaneum). Journal of Agricultural Techonology, 4(1): 219-229.

Barnes, J.P., Putnam, A.R., 1986. Evidence for allelopathy by residues and aqueous extracts of rye (Secale cereale). Weed Science, 34(3): 384-390.

Blum, U., Gerig, T.M., Worsham, A.D., King, L.D., 1993. Modification of allelopathic effects of $p$ coumaric acid on morningglory seedling biomass by glucose, methionine, and nitrate. Journal of Chemical Ecology, 19(12): 2791-2811.

Chon, S.U., Kim, J.D., 2002. Biological activity and quantification of suspected allelochemicals from alfaalfa plant parts. Journal of Agronomy and Crop Science, 188(4): 281-285.

Daizy, R.B., Singh, H.P., Kohli, R.K., Saxena, D.B., Kaur, S., 2002. Allelopathic effects of parthenin against two weedy species, Avena fatua and Bidens pilosa. Environmental and Experimental Botany, 47(2): 149-155

Dandelot, S., Robles, C., Pech, N., Cazaubon, A., Verlaque, R., 2008. Allelopathic potential of two invasive alien Ludwigia spp. Aquatic Botany, 88(4): 311-316

Dayan, F.E., Duke, S.O., 2006. Allelopathy. In: M.J. Reigosa, N. Pedrol, L. Gonzalez (Eds.), Clues in the Search for New Herbicides. Springer, Dordrecht, The Netherlands, pp. 63-84.

Dimitrović, S., Simonović, A., Mitić, N., Savić, J., Cingel, A., Filipović, B., Niković, S., 2015. Hairy root exudates of allelopathic well Chenopodium murale L. induce oxidative stres and down-regulate core cell cycle genes in Arabidopsis and wheat seedlings. Plant Growth Regullation, 75(1) : 365382

Ferguson, J.J., Rathinasabapathi, B., 2012. How plants suppress other plants. African Traditional Herbal Research Clinic, 7(3): 15-17.

Han, C., Pan, K., Wu, N., Wang, J., Li, W., 2008. Allelopathic effect of ginger on seed germination and seedling growth of soybean and chive. Scientia Horticulturae, 116(3): 330-336.

Hedge, I.C., 1982. Salvia L. - In: P.H. Davis (Ed.), Flora of Turkey and East Aegean Islands 7, Edinburgh University Perss, Edinburgh, pp. 400461.

Heldt, H.W., 1997. Plant Biochemistry and Molecular Biology. Oxford University Press, Oxford.

Huber- Morath, A., 1978. Verbascum L. In: P.H. Davis (Ed.), Flora of Turkey and East Aegean Islands 6, Edinburgh University Perss, Edinburgh, pp. 461603.

Inderjit., Duke, S.O., 2003. Ecophysiological aspects of allelopathy. Planta, 217(4): 529-539.

Jefferson, L.V., Pennacchio, M., 2003. Allelopathic effects of foliage extracts from four Chenepodiaceae species on seed germinaton. Journal of Arid Environments, 55(2): 275-285.
Jinhu, M., Guofang, X., Wenxiu, Y., Leilei, M., Mei, G., Yuguo, W., Yuanhuai, H., 2012. Inhibitory effects of leachate from Eupatorium adenophorum on germination and growth of Amaranthus retroflexus and Chenopodium glaucum. Acta Ecologica Sinica, 32(1): 50-56.

Kruse, M., Strandberg, M., Strandberg, B., 2000. Ecological Effects of Allelopathic Plants - A Review. National Environmental Research Institute, Technical Report No:315, Silkeborg, Denmark.

Maharjan, S., Shrestha, B.B., Jha, P.K., 2007. Allelopathic effects of aqueous extract of leaves of Parthenium hysterophorus L. on seed germination and seedling growth of some cultivated and wild herbaceous species. Scientific World, 5(5): 33-39.

Mao, J., Yang, L., Shi, Y., Hu, J., Piao, Z., Mei, L., Yin, S., 2006. Crude extract of Astragalus mongholicus root inhibits crop seed grmination and soil nitrifying activity. Soil Biology \& Biochemistry, 38(2): 201208

Molisch, H., 1937. Der Einfluss einer Pflanze auf die andere-Allelopathie. Fischer, Jena, Germany.

Noguchi, H.K., Fushimia, Y., Shigemorib, H., 2009. An allelopathic substance in red pine needles (Pinus densiflora). Journal of Plant Physiology, 166(4): 442-446.

Oueslati, O., 2003. Allelopathy in two durum wheat (Triticum vulgare) varieties. Agriculture, Ecosystem and Environment, 96(1-3): 161-163.

Oyun, M.B., 2006. Alleopathic potentialities of Gliricidia sepium and Acacia auriculiformis on the germination and seedling vigours of maize (Zea mays L.) American Journal of Agricultural and Biological Science, 1(3): 44-47.Rice, E. L., 1984. Allelopathy. Second Edition, Academic Press, Orlando.

Salmaci, E., Kordali, S., Kotan, R., Cakır, A., Kaya, Y., 2007. Chemical compositions, antimicrobial and herbicidal effects of essential oils isolated from Turkish Tanacetum aucheranum and Tanacetum chiliophyllum var. chiliophyllum. Biochemical Systematics and Ecology, 35(9): 569-581.

Shan, B., Cai, Y.Z., Sun, M., Corke, H., 2005. Antioxidant capacity of 26 spice extracts and characterization of their phenolic constituents. Journal of Agriculture and Food Chemistry, 53(20) : 7749-7759.

Singh, N.B, Thapar, R., 2003. Allelopathic influence of Cannabis sativa on growth and metabolism of Parthenium hysterophorus. Allelopathy Journal, 12(1): 61-70.

Sitthinoi, P., Lertmongkol, S., Chanprasert, W., Vajrodaya, S., 2017. Allelopathic effects of jungle rice [Echinochloa colona (L.) Link] extract on seed germination and seedling growth of rice. Agriculture and Natural Resources, 51(2): DOI: 10.1016/j.anres.2016.09.004 (In Press).

Song, J., 1990. Allelop athy among plants. Chinese Journal of Ecology, 9(6): 43-47. 
Taiz, L., Zeiger, E., 2008. Bitki Fizyolojisi. Üçüncü Baskıdan Çeviri (Çeviri Editörü: Prof. Dr. İsmail Türkan), Palme Yayıncilık, Ankara.

Tefera, T., 2002. Allelopathic effect of Parthenium hysterophorus extracts on seed germination and seedling growth of Eragrastif tef. Journal Agronomy\&Crop Science, 188(5): 306-310.

Torres, A., Olivia, R.M., Castellano, D., Cross, P., 1996. A science of the future. In: Proceedings of the 1st World Congress on Allelopathy, Cadiz, Spain, University of Cadiz, September 16-20, p. 278.

Türker, M., Battal, P., Ağar, G., Şahin, M., Erez, M.E., Yildırım, N., 2008. Allelopathic effects of plants extracts on physiological and cytological processes during maize seed germination. Allelopathy Journal, 21(2): 273-286.
Wang, C., Zhou, J., Jiang, K., Liu, J., 2017. Differences in leaf functional traits and allelopathic effects on seed germination and growth of Lactuca sativa between red and green leaves of Rhus typhina. South African Journal of Botany, 111: 17-22.

Wu, L., Guo, X., Harivandi, A.M., 1998. Allelopathic effects of phenolic acids detected in buffalograss (Buchloe dactyloides) clippings on growth of annual bluegrass (Роа апnиа) and buffalograss seedlings. Environmental and Experimental Botany, 39(2): 159-167.

Zhang, C., Fu, S., 2009. Allelopathic effects of eucalyptus and the establishment of mixed stands of eucalyptus and native species. Forest Ecology and Management, 258(7): 1391-1396. 